\title{
Decompression sickness in caisson workers
}

\author{
SAMIR H. EL GHAWABI, MOHAMED B. MANSOUR, FATMA L. \\ YOUSSEF, MOHAMED H. EL GHAWABI, and MOHAMED M. ABD \\ EL LATIF \\ The National Institute of Occupational Safety and Health, Heliopolis, Cairo, U.A.R.
}

El Ghawabi, S. H., Mansour, M. B., Youssef, F. L., El Ghawabi, M. H., and Abd El Latif, M. M. (1971). Brit. J. industr. Med., 28, 323-329. Decompression sickness in caisson workers. An investigation of 55 bridge construction workers is reported. The overall bends rate was $0.97 \%$. (The term 'bends' as used in this study is defined in the paper.) Chokes were encountered in $67.27 \%$ of workers. A clinical, haematological, and radiological study was performed.

Definite bony changes were found in $43.6 \%$ of all workers; $91.6 \%$ of these had lesions around the elbow. The presence of dense areas in the neck of the scapula is reported in two cases for the first time. The relatively high haematocrit value is thought to play a part in the pathogenesis of bone infarction through its relation with blood viscosity.

Despite the marked improvements in diving dresses and the very comprehensive regulations governing work in subaquatic civil engineering, sporadic cases of severe and fatal decompression sickness still occur as a result of inadequate attention to decompression procedures (McCallum and Walder, 1953).

Bone necrosis, as a result of decompression sickness, was first noted by Twynam in 1888 (Kahlstrom, Burton, and Phemister, 1939). Additional information has been supplied by Taylor (1944), James (1945), Sartor (1947), Parodi (1948), Raymond (1948), Cavigneaux, Charles, Fuchs, and Tara (1949), McCallum and Walder (1953), Ronald (1953), Behnke (1955), Roche, Devic, Genevois, and Marin (1956), Tillman (1961), and Giuntini (1967). Although a high rate of bone lesions has recently been reported (Golding, Griffiths, Hempleman, Paton, and Walder, 1960; McCallum and Walder, 1966), very little information exists about the incidence of caisson disease of bone in different countries.
Salah (1950) reported the first case of decompression sickness encountered in an Egyptian diver but the sequelae of working in caissons, especially bony changes, have not been investigated in the United Arab Republic. The aim of this study was to evaluate the general health of caisson workers and to determine the frequency of bony and joint changes in such a group.

\section{Industrial process}

Pneumatic caissons, $26 \times 7 \times 2.1 \mathrm{~m}$, were used in bridge work for plugging the bottom of the foundation with concrete. Caissons were allowed to sink $20 \mathrm{~m}$ in thick slime until they reached a solid sandy layer and water was expelled from the working chamber by compressed air. The workers entered the chamber through an air lock, reached the caisson bottom by a vertical ladder, excavated the mud using buckets, and hoisted it up through a 'muck lock'. They securely plugged the bottom of the foundation with concrete after the caisson settled in the firm sand layer below. The air pressure in the caissons was expressed as gauge pressure in kilogrammes 
per square centimetre and it was varied according to the depth of caisson below water level to prevent water rising into the caisson before it was sealed with concrete. The maximum gauge pressure used was about $2.8 \mathrm{~kg} / \mathrm{cm}^{2}$ $\left(280 \mathrm{kN} / \mathrm{m}^{2}\right)$.

The work in each caisson was in three shifts, each of 11 men. The duration of each shift was eight hours, shortened to six hours when the pressure exceeded $2.5 \mathrm{~kg} / \mathrm{cm}^{2}\left(250 \mathrm{kN} / \mathrm{cm}^{2}\right)$. A general practitioner was in charge of the medical unit with two orderlies responsible for the first-aid room.

\section{Material and technique}

Clinical examination of 55 caisson workers at the Giza and Ramses Bridges was carried out. This included occupational, past, and present medical histories as well as family history, age, and smoking habits. The present medical history was verified by comparing it with the data obtained by the retrospective study of the official medical book in the company. Haematological examination included haemoglobin concentration (Sahli), erythrocyte count, total and differential leucocyte counts, and haematocrit values (standard Wintrobe method).

Antero-posterior and lateral $x$-rays of the shoulder, elbow, hip, wrist, knee, and ankle joints, exposing a large part of the diaphysis in each case, were performed.

A control group of 35 construction workers with no previous experience of compressed air work, was examined radiologically and haematologically. The age distribution of this control group was nearly identical with that of the caisson workers.

\section{Results}

The age distribution and duration of exposure of all workers exposed to high pressure are shown in Table 1.

Bends

Only caisson workers with symptoms sufficiently severe to bring them back for an injection of novalgin had been considered as having decompression

\section{TABLE 1}

WORKERS DISTRIBUTED ACCORDING to AGe, DURAtion of Exposure AND Positive Bony Lesions

\begin{tabular}{|c|c|c|c|c|c|c|c|c|}
\hline \multirow{2}{*}{$\begin{array}{l}\text { Age } \\
(y r)\end{array}$} & \multirow{2}{*}{$\begin{array}{c}\text { No. of } \\
\text { workers }\end{array}$} & \multicolumn{6}{|c|}{ Period of exposure $(y r)$} & \multirow{2}{*}{$\begin{array}{c}\text { No. of } \\
\text { workers } \\
\text { with } \\
\text { bony } \\
\text { changes }\end{array}$} \\
\hline & & $<1$ & $1-$ & $2-$ & $3-$ & $4-$ & $5-$ & \\
\hline $\begin{array}{l}25- \\
30- \\
35- \\
40- \\
45- \\
50-\end{array}$ & $\begin{array}{r}16 \\
14 \\
16 \\
7 \\
1 \\
1\end{array}$ & $\begin{array}{l}1 \\
- \\
-\end{array}$ & $\begin{array}{l}1 \\
3 \\
1 \\
- \\
-\end{array}$ & $\begin{array}{l}3 \\
4 \\
2 \\
- \\
-\end{array}$ & $\begin{array}{r}7 \\
4 \\
11 \\
5 \\
-\end{array}$ & $\begin{array}{l}2 \\
3 \\
- \\
- \\
-\end{array}$ & $\begin{array}{l}2 \\
2 \\
2 \\
1 \\
1\end{array}$ & $\begin{array}{l}5 \\
6 \\
8 \\
4 \\
1\end{array}$ \\
\hline
\end{tabular}

sickness because the minor pains, 'niggles', after decompression are too indefinite for quantitative study (Golding et al., 1960). The type of pain experienced in our series is similar to that described by Behnke (1955).

There were 330 attacks in an estimated total of 34164 compressions giving an overall bends rate of $0.97 \%$. Seven workers did not suffer from an attack of bends. Of this group, six weighed less than $65 \mathrm{~kg}$ (Table 2). Four workers (all weighing less than $65 \mathrm{~kg}$ ) suffered from a single attack but the rest of

\section{TABLE 2}

Distribution OF Workers BY Body Weight and NUMBER OF WORKERS NOT SUFFERING FROM BENDS in EACH Group aNd with Total Number of Bends IN EACH Group

\begin{tabular}{c|c|c|c}
\hline $\begin{array}{c}\text { Body weight } \\
(\mathrm{kg})\end{array}$ & $\begin{array}{c}\text { No. of } \\
\text { workers }\end{array}$ & $\begin{array}{c}\text { No. of workers not } \\
\text { suffering bends }\end{array}$ & $\begin{array}{c}\text { Total no. } \\
\text { of bends in } \\
\text { this group }\end{array}$ \\
\hline $45-54$ & 15 & 2 & 49 \\
$55-64$ & 31 & 4 & 186 \\
$65-74$ & 8 & 1 & 91 \\
Over 75 & 1 & - & 4 \\
\hline
\end{tabular}

the workers had multiple attacks. We found that the bends rate began to rise when the pressure exceeded $2 \cdot 1 \mathrm{~kg} / \mathrm{cm}^{2}\left(210 \mathrm{kN} / \mathrm{m}^{2}\right)$, then rose to a high level for a brief period, and tended to fall away thereafter even though the pressure was maintained. Figure 1 shows the relative distribution of attacks of bends in different joints of the body.

\section{Chokes}

These occurred in 37 workers $(67 \cdot 27 \%)$. They felt a

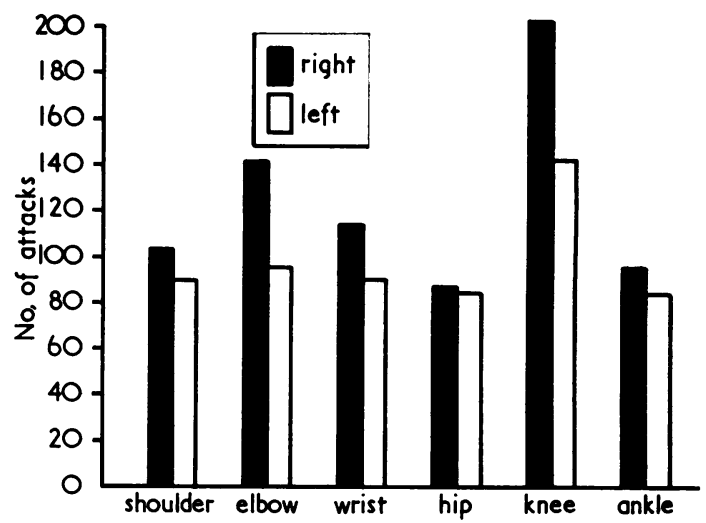

FIG. 1. Relative distribution of attacks of bends in different joints of the body. 
TABLE 3

Haematological Studies in 41 Caisson Workers compared with Controls

\begin{tabular}{|c|c|c|c|c|c|c|c|c|c|c|c|}
\hline \multirow{2}{*}{ Group } & \multicolumn{2}{|c|}{ Haemoglobin } & \multirow{2}{*}{$\begin{array}{c}\text { Haemotocrit } \\
\text { value, } \%\end{array}$} & \multirow{2}{*}{$\begin{array}{c}\text { Red blood } \\
\text { cells } \\
\times 10^{3} / \mathrm{mm}^{3}\end{array}$} & \multirow{2}{*}{$\begin{array}{c}\text { Total } \\
\text { leucocyte } \\
\text { count } \\
/ \mathrm{mm}^{3}\end{array}$} & \multirow{2}{*}{$\begin{array}{c}\text { Eosino- } \\
\text { phils } \\
\%\end{array}$} & \multirow{2}{*}{$\begin{array}{c}\text { Basophils } \\
\%\end{array}$} & \multicolumn{2}{|c|}{ Polymorphs } & \multirow{2}{*}{$\begin{array}{c}\text { Lympho- } \\
\text { cytes } \\
\%\end{array}$} & \multirow{2}{*}{$\begin{array}{c}\text { Monocytes } \\
\%\end{array}$} \\
\hline & $\%$ & g. $/ 100 \mathrm{ml}$ & & & & & & Staff & $\begin{array}{c}\text { Seg- } \\
\text { mented }\end{array}$ & & \\
\hline $\begin{array}{l}\text { Caisson } \\
\text { workers }\end{array}$ & $\begin{array}{c}89 \cdot 9 \\
(69-117)\end{array}$ & $\begin{array}{l}14 \cdot 4 \\
(11-18 \cdot 7)\end{array}$ & $\begin{array}{c}44 \cdot 14 \\
(38-48)\end{array}$ & $\begin{array}{rl}4 & 501 \\
(3 & 210- \\
5 & 940)\end{array}$ & 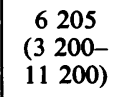 & $\begin{array}{c}2 \cdot 5 \\
(0-11)\end{array}$ & $\begin{array}{c}0 \cdot 7 \\
(0-2)\end{array}$ & $\begin{array}{l}2 \cdot 8 \\
(0-7)\end{array}$ & $\begin{array}{c}59 \cdot 3 \\
(50-72)\end{array}$ & $\begin{array}{c}31 \cdot 9 \\
(23-41)\end{array}$ & $\begin{array}{l}3 \cdot 17 \\
(0-7)\end{array}$ \\
\hline Controls & $\begin{array}{c}85 \\
(70-105)\end{array}$ & $\begin{array}{l}14 \cdot 6 \\
(11 \cdot 1-16 \cdot 8)\end{array}$ & $\begin{array}{c}39 \cdot 6 \\
(32-43)\end{array}$ & $\begin{array}{rl}4 & 200 \\
(3680- \\
5 & 109)\end{array}$ & $\begin{array}{c}5800 \\
(4200- \\
10500)\end{array}$ & $\begin{array}{c}2 \cdot 8 \\
(0-10)\end{array}$ & $\begin{array}{c}0 \cdot 8 \\
(0-2)\end{array}$ & $\begin{array}{c}2 \cdot 6 \\
(0-7)\end{array}$ & $\begin{array}{c}56 \cdot 8 \\
(48-66)\end{array}$ & $\begin{array}{c}30 \cdot 7 \\
(26-40)\end{array}$ & $\begin{array}{l}3 \cdot 0 \\
(0-7)\end{array}$ \\
\hline
\end{tabular}

Mean values; ranges in parentheses.

sensation of retrosternal distress lasting for a variable time. The sensation was usually relieved after vomiting in 27 workers. The symptom occurred in 14 workers once, in 13 workers twice, and in the remaining 10 workers more than twice. Behnke's (1955) sign was not observed in our series as the workers were forbidden to inhale tobacco smoke for two hours after coming out of the air locks.

\section{Cutaneous manifestations}

Thirty-eight $(69 \%)$ complained of itching after coming out of the air lock. This itching was usually generalized and occurred especially when the weather was cool. Erythema and mottling of the skin was present in only five workers.

\section{Blood examinations}

The blood of only 41 workers was examined as the rest refused. The results were compared with those of the 35 controls. The blood picture was nearly the same as in the control group (Table 3) except for the

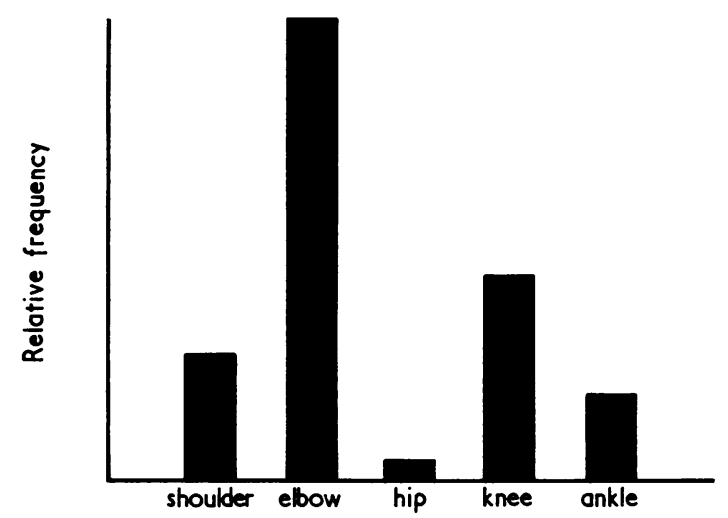

FIG. 2. Frequency of bony lesions in different regions of the body. haematocrit values which were significantly higher. The pooled standard deviation is 2.328 , while the standard error of the difference in the two means is $0.536 ; t=8.4, \mathrm{P}<0.001$.

\section{Bony changes}

The classification of McCallum and Walder (1966) was used. Figure 2 shows the frequency of bony lesions in different regions of the body. Definite bony changes were found in 24 men $(43.6 \%)$ while doubtful evidence was present in another 15 men $(27 \cdot 2 \%)$. This latter group will have to be followed up as such cases may become definite cases as time passes.

\section{Elbow lesions (Fig. 3)}

The elbow was affected in 22 men $(91.6 \%)$ out of the 24 positive cases. The lower ends of both humeri were affected in 14 men. Unilateral affection of the lower end of the humerus occurred in seven men on the right side and in one on the left side. The upper ends of both ulnae were affected in 12 men, the upper end of the right ulna in nine men, and the upper end of the left ulna in one man. The upper ends of both radii were affected in five men, the right radius in seven, and the left in two men. The radius was not affected in every case compared with the humerus or ulna.

\section{Knee lesions}

Bony lesions in the knee region were present in $\mathbf{1 0}$ men $(41.6 \%)$ out of the 24 positive cases. The lower ends of both femora were affected in two men while in three men one or other side was affected. Bilateral lesions in the upper ends of the tibiae were found in two men, on the right side alone in three, and on the left side alone in two men. Periosteal reaction (periostitis) along the lateral border of the upper part of the metaphysis of the tibia occurred in seven men, four of whom had associated bony lesions in the same tibia. The upper end of the fibula was 


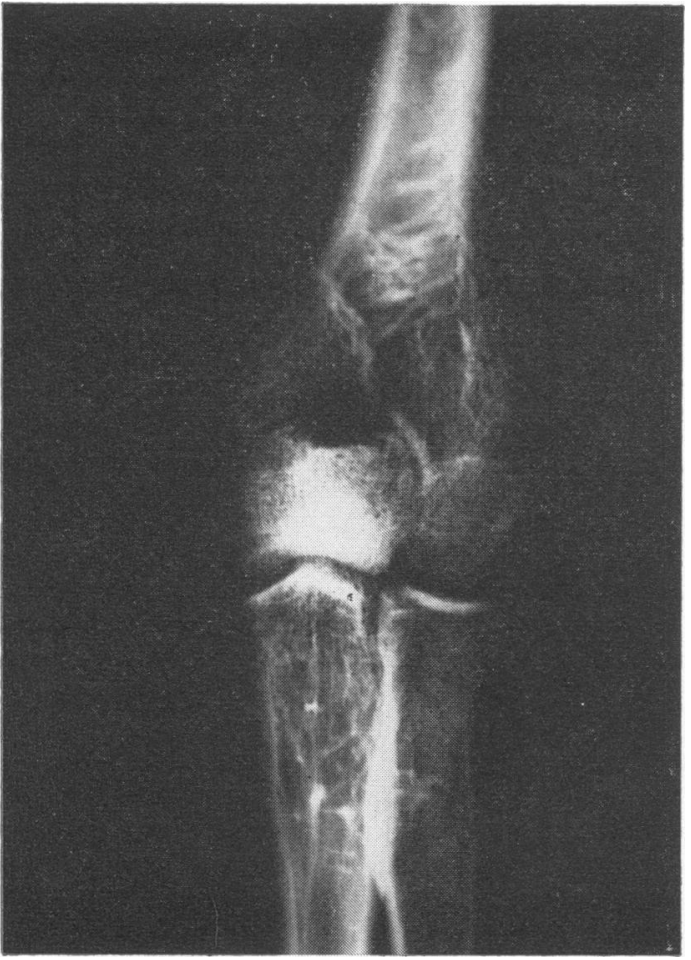

FIG. 3. Right elbow

Humerus: juxta-articular dense area at junction of trochlea and capitulum opposite epiphyseal scar together with cyst in médial epicondyle and irregular calcified area in metaphysis of shaft.

Ulna: juxta-articular linear opacity in middle of upper surface of coronoid process with multiple irregular dense areas mainly in metaphysis.

Radius: juxta-articular dense area in middle of head of radius with calcified area opposite radial tuberosity.

affected in five men; one case was bilateral and the remainder were on the right side. One man had a definite small cyst in the head of the right fibula, with a well-defined sclerosed margin, especially along its lateral border (Fig. 4). Biopsy was refused.

\section{Shoulder region lesions}

Of the cases with positive bony lesions, six $(25 \%)$ were affected in the upper end of the humerus. Four cases were left-sided, the other two were right-sided. No bilateral lesions were detected. In two cases, the neck of the scapula showed irregular dense areas easily differentiated from bone islands (Fig. 5).

\section{Ankle region lesions}

Of those cases with bony lesions, four (16.6\%) showed lesions in the right ankle region. In one man there was sequestration of the lateral part of the cortex of the lower end of the tibia. This juxtaarticular lesion was accompanied by pain and slight difficulty in walking. In the other three men there were symptomless dense areas at the junction of the upper two-thirds of the tibial shaft with the lower third.

\section{Hip lesions}

Only one $(4 \cdot 16 \%)$ of all the positive cases showed a radiotranslucent area in the neck of the femur on the left side.

\section{Feet and hands}

There were no radiologically significant lesions.

Our radiological findings in the 24 positive cases could be summarized according to the McCallum and Walder classification as follows:

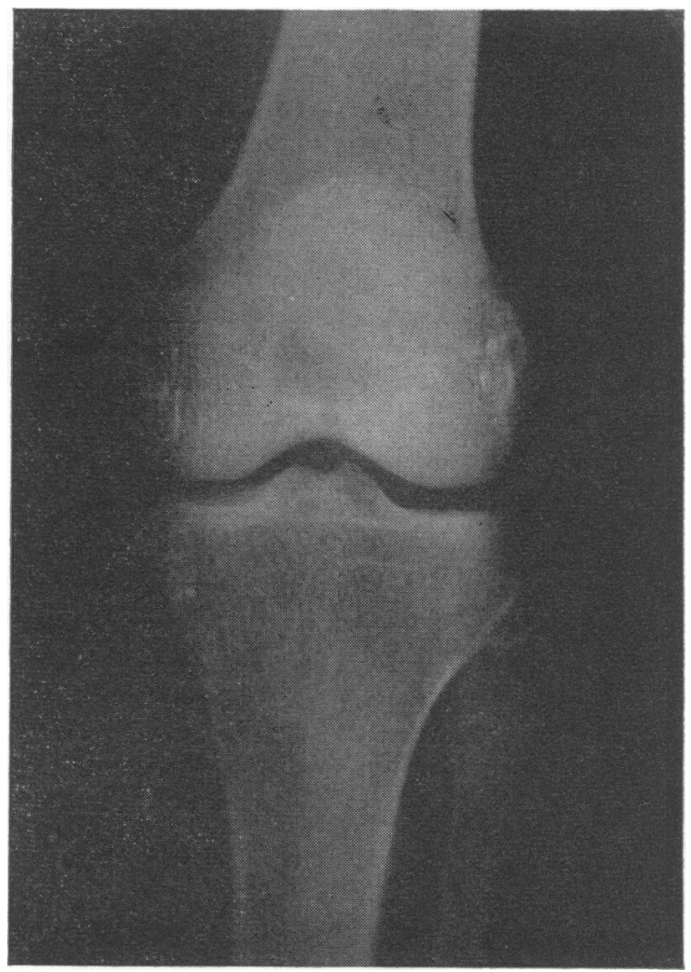

FIG. 4. Right knee.

Juxta-articular linear opacity along both tibial condyles with dense area in its shaft. Presence of definite cyst in head of fibula with linear opacity along its lateral margin. 


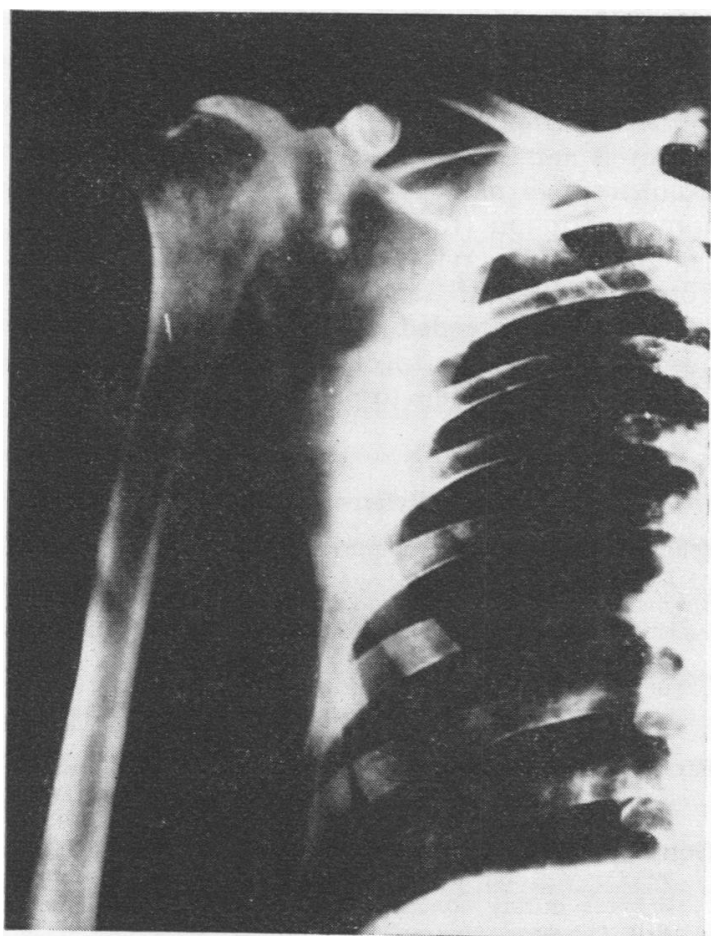

I1G. 5. Left shoulder: a dense area in neck of scapula.

\section{A. Juxta-articular lesions}

$\begin{array}{lcc} & \text { Cases } & \% \\ \text { Dense areas } & 55 & 100 \\ \text { Spherical segmental opacities } & 1 & 4 \cdot 16 \\ \text { Linear opacities } & 16 & 29.09 \\ \text { Transradiant subcortical bends } & 5 & 20.08 \\ \text { Collapse of articular cortex } & 0 & 0 \\ \text { Sequestration of part of cortex } & 1 & 4 \cdot 16 \\ \text { Osteoarthritis } & 0 & 0 \\ \text { Head, neck, and shaft lesions } & & \\ \text { Dense areas } & 55 & 100 \\ \text { Irregular calcified areas } & 5 & 20.08 \\ \text { Transradiant areas and cysts } & 11 & 45 \cdot 8\end{array}$

\section{Discussion}

Several years ago caisson disease was believed to be preventable by adequate prophylaxis and careful attention to decompression procedures. But unhappily this prospect has not been achieved because bony lesions appear to be more frequent than had hitherto been realized. A great deal of attention has recently been focused on bony lesions in such workers chiefly because of the recent increase in insurance costs for tunnel workers in some countries (Kleinfeld and Wilson, 1956).
Clinical manifestations of decompression sickness have been well described and its pathogenesis has been generally accepted since Paul Bert published his experimental findings in 1878 (Kahlstrom et al. 1939).

The presenting symptom of the disease is usually the pain (bends) and in our series it occurred in $87.27 \%$ of workers. The overall bends rate varied from $0.87 \%$ at the Tyne Pedestrian Tunnel (Paton and Walder, 1954) to $4 \%$ at a caisson in the Thames (Lewis and Paton, 1957) compared with our overall bends rate which was $0.97 \%$. The rate is influenced by many variables such as length of shift, height of pressure, high labour turnover, acclimatization, physical and mental characteristics of the workers, differences in temperature and humidity, and disciplinary problems (McCallum, 1968). However, the role of acclimatization is doubtful. We agree with Rózsahegyi (1959) that reduction in the sickness incidence was due not to adaptation but to a natural selection as those workers who frequently suffered gave up the caisson work. Our group of workers were previously ordinary construction workers and all of them were new to the job. Those who frequently suffered during the work in compressed air were allowed to return to their former jobs.

Chokes were the rather specific type of asphyxia encountered in $67.27 \%$ of workers. The attacks of chokes were relieved by vomiting in $73 \%$ of workers.

Cutaneous manifestations are early signs of compressed air illness. Most workers suffer from this complaint from time to time (Farris and Sicca, 1952). The pruritus has been attributed to the nitrogen bubbles in the sweat glands of the skin. The erythema and purplish mottling of the skin denote stasis of blood in the cutaneous vessels. Thorne (1941) has suggested that this is a result of nitrogen emboli in the skin capillaries.

The prevalence of definite bony lesions in our series was $43 \cdot 6 \%$. Cavigneaux and his colleagues (1949) gave a figure of $38 \%$; Rózsahegyi and Fried (1963) reported the lesions in $22.2 \%$ of cases, while McCallum and Walder (1966) reported an incidence of $30.4 \%$ in men who experienced more than 900 decompressions. Thus a figure of $43.6 \%$ is relatively high. It can be explained by incomplete adherence to the British decompression table. We found that the foremen had modified the use of the British table to give a decompression schedule which was less by about $25 \%$ than the minimum required by law. Walder (1967) stated that decompression given by the correct use of the British table is probably inadequate and that this may explain the high incidence of bony lesions.

The minimum exposure necessary to produce definite bony changes under these conditions is not known, but one man in our series who had never been exposed to high pressure before was found to 
have bony changes two months after the start of work in compressed air. In the series of McCallum and Walder (1966), the shortest period for bony changes to occur was three months. The possibility of bony lesions after a single exposure is supported by the experience of James (1945), who found aseptic bony necrosis in survivors from the submarine which sank in 1931; none of whom had suffered from caisson disease at any other time.

No relationship could be established between the number of decompressions and the prevalence of bony lesions or between the site of bends and the site of bony lesions. However, we agree with Rózsahegyi and Fried (1963) that the more attacks of bends a man has suffered the more likely he is to develop bone necrosis.

In the present series, positive radiological findings were mainly around the elbow $(91.6 \%$ in those with positive bony lesions). Apart from the work of Bell, Edson, and Harnick (1942) quoted by McCallum and Walder (1966), we have found no reference to bony lesions in the lower end of the humerus. All other authors described lesions in the proximal end of the humerus and in the proximal or distal ends of the femur (Cavigneaux et al., 1949; Jullien, 1956; Raymond, 1960; Golding et al., 1960; Rózsahegyi and Fried, 1963). This may be due partly to their techniques as some of them did not $x$-ray the elbow routinely (Golding et al., 1960; McCallum and Walder, 1966). This also might explain why, when arthrosis attributed to decompression sickness was included in the list of notifiable occupational diseases in France in 1949, it was restricted to the shoulder and hip (Raymond, 1960). Thus the explanation put forward by McCallum and Walder that posture is a factor in determining the site of the lesion has to be revised, especially if those authors can possibly obtain $x$-rays of the elbows in their series.

A new finding in our series was the presence in two men of dense areas in the neck of the scapula. These irregular dense areas could be easily differentiated from bone islands which are ovoid or oblong, uniformly dense, compact bone. The fact that the left shoulder was affected in four out of six cases can be explained by the mode of origin of the left subclavian artery as opposed to the right, as suggested by James (1945).

Lesions around the ankle can easily be missed as dense areas in the lower end of the tibia occur usually far from the joint at the junction of the upper twothirds with the lower third of the shaft. No explanation can be offered why all the lesions occurred on the right side.

In the present study a statistically significant high haematocrit value was found in caisson workers compared with the control group. The relationship between blood viscosity and haematocrit value has been emphasized by Miale (1967), and the increased viscosity has been suggested as an aetiological factor in coronary thrombosis (Burch and DePasquale, 1962). Experimentally it was shown that air embolism is not the only cause of bony infarction (Kahlstrom et al., 1939). James (1945) attributed bony infarction to an increased intravascular agglutination of erythrocytes, blood stasis resulting from air embolism, and the mechanical blocking effect of gas-distended blood vessels. We believe that all these factors together with increased blood viscosity may combine to produce the bony lesions.

\section{References}

Behnke, A. R. (1955). Decompression sickness. Milit. Med., 117, 257-271.

Burch, G. E., and DePasquale, N. P. (1962). Editorial. Hematocrit, blood viscosity and myocardial infarction. Amer. J. Med., 32, 161-163.

Cavigneaux, A., Charles, A., Fuchs, S., and Tara, S. (1949). Les lésions osseuses ignorées des tubistes. Arch. Mal. prof., 10, 359-361.

Farris, G., and Sicca, U. (1952). Manifestazioni cutanee nei lavoratori dei cassoni pneumatici. Rass. Med. industr., 21, 350-366.

Golding, F. C., Griffiths, P., Hempleman, H. V., Paton, W. D. M., and Walder, D. N. (1960). Decompression sickness during construction of the Dartford Tunnel. Brit. J. industr. Med., 17, 167-180.

Giuntini, C. N. (1967). Considerazioni sulle osteoartropatie da aeroembolismo disbarico. Med.d. Lavoro, 58, 161-200.

James, C. C. M. (1945). Late bone lesions in caisson disease. Lancet, $2,6.8$.

Jullien, G. (19:56). Étude des réactions pathologiques consécutives à la plongée sous-marine et au travail dans l'air comprimé. Arch. Mal. prof., 17, 228-236.

Kahlstrom, S. C., Burton, C. C., and Phemister, D. B. (1939). Aseptic necrosis of bone. Surg. Gynec. Obstet., 68, 129146.

Kleinfeld, M., and Wilson, J. T. (1956). Decompression sickness (compressed-air illness) in a tunneling operation. Arch. industr. Hlth, 14, 539-542.

Lewis, H. E., and Paton, W. D. M. (1957). Decompression sickness during the sinking of a caisson. A study of some of the factors in the pathogenesis of caisson disease. Brit.J. industr. Med., 14, 5-12.

McCallum, R. I. (1968). Decompression sickness: a review. Brit. J. industr. Med., 25, 4-21.

, and Walder, D. N. (1953). Compressed-air illness on Tyneside. Lancet, 1, 464-467.

- and - (1966). Bone lesions in compressed air workers. J. Bone Jt Surg., 48B, 207-235.

Miale, J. B. (1967). Laboratory Medicine, Hematology, 3rd ed., C. V. Mosby, Saint Louis.

Parodi, V. M. (1948). Rilievi semeiologici e clinici, nelle forme osteomioartralgiche della malattia dei cassoni. Med. d. Lavoro, 39, 73-79.

Paton, W. D. M., and Walder, D. N. (1954). Compressed Air Illness. Spec. Rep. Ser. med. Res. Coun. (Lond.), No. 281. H.M.S.O., London.

Raymond, V. (1948). Les ostéo-arthrites pneumatiques. Lésions osseuses des tubistes et des scaphandriers. Arch. Mal. prof., 9, 437-442.

(1960). Arthroses baro-traumatiques. Arch. Mal. prof., 21, 609-621.

Roche, L., Devic, M., Genevois, M., and Marin, A. (1956). La tomographie osseuse dans l'ostéoarthropathie des 
caissons. Arch. Mal. prof., 17, 597-601.

Ronald, J. (1953). Aseptic necrosis of bone in caisson disease. Lancet, 2, 855-856.

Rózsahegyi, I. (1959). Die Rolle der Disposition bei der Entstehung der Dekompressionskrankheit. Arch. Gewerbepath. Gewerbehyg., 17, 347-353.

, and Fried, L. (1963). Untersuchungen über die Entstehung und Dynamik der chronischen osteoarthropathie der Caissonarbeiter. Z. ges. Hyg., 9, 915-924.

Salah, M. (1950). Compressed air disease (Caisson disease). Report of the 1st case encountered in an Egyptian diver. J. Egypt med. Ass., 33, 56-64.

Sartor, E. (1947). Skelettförändringar vid tryckluftsjuka (English summary). Nord. Med., 35, 1551-1554.

Taylor, H. K. (1944). Aseptic necrosis in adults: caisson workers and others. Radiology, 42, 550-469.
Thorne, I. J. (1941). Caisson disease. A study based on three hundred cases observed at the Queens-Midtown Tunnel project, 1938. Amer. med. Ass., 117, 585-588.

Tillmann, R. (1961). Knochennekrose der Schultergelenke bei Tauchern. Z. ges. Hyg., 7, 89-98.

Walder, D. N. (1967). Decompression sickness in Tunnel workers. In: The Effects of Abnormal Physical Conditions at Work. The Report of a Meeting held jointly by the British Occupational Hygiene Society, the Ergonomics Research Society and The Soziety of Occupational Medicine, 1967. Edited by C. N. Davies, P. R. Davis, and F. H. Tyrer, pp. 101-110. Livingstone, Edinburgh and London.

Received for publication September 9, 1970. 